\title{
Clinical efficacy of the highly sensitive hepatitis C virus RNA quantitative assay in patients with relapse following interferon-based therapy with second-generation direct-acting antivirals
}

\author{
TORU ISHIKAWA, SATOSHI ABE, TAKAYUKI WATANABE, YUJIRO NOZAWA, TOMOE SANO, \\ AKITO IWANAGA, KEIICHI SEKI, TERASU HONMA and TOSHIAKI YOSHIDA
}

Department of Gastroenterology and Hepatology, Saiseikai Niigata Daini Hospital, Niigata 950-1104, Japan

Received January 18, 2016; Accepted April 5, 2016

DOI: 10.3892/br.2016.660

\begin{abstract}
For refractory chronic hepatitis C, interferon (IFN)-based triple-agent combination therapy with second-generation direct-acting antivirals (DAAs) has been established as the standard treatment method. The rate of decrease in the viral load and the negative conversion of hepatitis $\mathrm{C}$ virus (HCV) RNA in the early phase following treatment initiation are considered important factors for predicting the therapeutic outcome. In the present study, the Roche Cobas AmpliPrep/COBAS TaqMan (CAP/CTM) HCV v2.0 assay and the AccuGENE m-HCV RNA quantitative assay [Abbott RealTime HCV (ART) assay] were analyzed for their clinical efficacy and ability to predict therapeutic outcomes in the early phase in patients with relapse following IFN-based second-generation DAA therapy. Of the 56 patients who received IFN-based second-generation DAA therapy since December 2013, 6 achieved an end-of-treatment response (ETR), but subsequently experienced relapse. In these 6 patients, fluctuations in viral loads in the early phase detected by the CAP/CTM and ART assays were compared. At 4 weeks after treatment initiation, 4 of the 6 patients were diagnosed as negative by the CAP/CTM assay, whereas 2 of these 4 patients were not identified as negative by the ART assay. Of the 2 patients, one was signal-positive with an $\mathrm{HCV}$ RNA load $<1.08 \mathrm{Log} \mathrm{IU} / \mathrm{ml}$, and the other patient had a viral load of $1.12 \mathrm{Log} \mathrm{IU} / \mathrm{ml}$. At 8 weeks after treatment initiation, 1 patient was found to be negative by the CAP/CTM assay, but signal-positive with a viral load $<1.08 \mathrm{Log}$ IU/ml by the ART assay. From 4 to 8 weeks after treatment initiation, 3 of the 6 patients appeared to be discrepant cases. In conclusion, of the 6 patients who achieved an ETR, 4 were determined to have achieved a rapid virological response (RVR) by the CAP/CTM
\end{abstract}

Correspondence to: Dr Toru Ishikawa, Department of Gastroenterology and Hepatology, Saiseikai Niigata Daini Hospital, 280-7 Teraji, Niigata 950-1104, Japan

E-mail: toruishi@ngt.saiseikai.or.jp

Key words: quantitative polymerase chain reaction, hepatitis $\mathrm{C}$ virus RNA, interferon, predicting efficacy of therapy assay, but may not have actually become negative. The ART assay is highly sensitive, has a wide measurement range, may be suitable for monitoring HCV RNA loads, and is expected to have an important role in providing a predictive marker for early therapeutic outcomes. In discrepant cases in which no RVR is proved by either assay, it was assumed important to consider continuation of treatment and to attempt to achieve a sustained virological response.

\section{Introduction}

At present, for refractory chronic hepatitis $\mathrm{C}$, interferon (IFN)-based triple-agent combination therapy with second-generation direct-acting antivirals (DAAs) has been established as the standard treatment method. In IFN-based therapy, negative conversion of hepatitis $\mathrm{C}$ virus (HCV) RNA in the early phase following treatment initiation is considered an important factor for predicting treatment outcomes (1-4).

Recently, HCV-RNA measuring systems that are more sensitive compared to conventional HCV-RNA qualitative assays have been developed and reported to be clinically useful $(5,6)$.

The AccuGENE m-HCV RNA quantitative assay [Abbott RealTime HCV (ART) assay], which was developed as a highly sensitive HCV RNA quantitative assay by Abbott Laboratories (Abbott Park, IL, USA), has a minimum detection sensitivity of $12 \mathrm{IU} / \mathrm{ml}$ and enables the quantification and detection of lower viral loads compared to that allowed by the conventional Cobas TaqMan HCV quantitative assay [Cobas AmpliPrep/Cobas TaqMan (CAP/CTM) assay], developed by Roche Diagnostics (Basel, Switzerland).

In the present study, these two highly sensitive HCV-RNA quantitative assays were compared and analyzed for their ability to predict therapeutic outcomes in patients with relapse following triple-agent combination therapy with pegylated interferon (PEG-IFN), ribavirin (RBV) and simeprevir (SMV).

\section{Subjects and methods}

Study design. Between December 2013 and October 2015, patients received $100 \mathrm{mg} /$ day SMV per os (Sovriad; Janssen Pharmaceutical K.K., Tokyo, Japan), combined with weekly 
subcutaneous injections of $1.5 \mu \mathrm{g} / \mathrm{kg}$ of PEG-IFN $\alpha 2 \mathrm{~b}$ (Peg-Intron with weekly subcutaneous and per os administration of 600-1,000 mg/day of RBV (Rebetol; MSD) in accordance with the prescribing information for 12 weeks followed by PEG-IFN $\alpha 2$ b and RBV between weeks 12 and 24 .

Dose reductions or discontinuation of SMV, PEG-IFN and RBV were according to the judgment of the treating physicians. Patients were followed up for $\geq 24$ weeks after the final treatment administration to assess the sustained virological response (SVR).

SVR24 was defined as undetectable serum HCV RNA levels at 24 weeks after the end-of-treatment (EOT).

Patients. The present study included 6 patients with genotype 1 chronic hepatitis $\mathrm{C}$ with a high viral load who achieved an EOT response (ETR) but subsequently experienced a relapse.

Assays. The CAP/CTM assay, which is the first-generation COBAS ${ }^{\circledR}$ assay developed by Roche Diagnostics, and the ART assay, developed by Abbott Laboratories, were used for the measurements, following the manufacturer's protocols.

Viral kinetics in the HCV-RNA loads detected by these two assays were compared and analyzed at each measurement point on treatment weeks 2, 4, 8, 12, 16, 20 and 24, at EOT and at 24 weeks after EOT. A negative response signifies no detection of HCV RNA.

\section{Results}

Patient characteristics. The patient clinical characteristics are shown in Table I. The mean age was $73.8 \pm 6.5$ years, and 3 patients $(50 \%)$ were male and $3(50 \%)$ were female. The interleukin-28B major allele was present in 1 patient, and the minor allele was present in the others.

Assay diagnosis. At 4 weeks after treatment initiation, 4 of the 6 patients were diagnosed as negative by the CAP/CTM assay, whereas 2 of these 4 patients were not found to be negative by the ART assay. Of the 2 patients, one was signal-positive with an HCV RNA load $<1.08 \mathrm{Log} \mathrm{IU} / \mathrm{ml}$, and the other patient had a viral load of $1.12 \mathrm{Log} \mathrm{IU} / \mathrm{ml}$. At 8 weeks after treatment initiation, 1 patient was found to be negative by the CAP/CTM assay, but signal-positive with a viral load $<1.08 \mathrm{Log}$ IU/ml by the ART assay of one patient. From 4 to 8 weeks after treatment initiation, 3 of the 6 patients appeared to be discrepant cases (Table II).

\section{Discussion}

Antiviral therapy for chronic hepatitis $\mathrm{C}$ was initiated with IFN alone in the 1990s. Until recently, standard treatment for chronic HCV genotype 1 infection was PEG-IFN in combination with RBV $(7,8)$.

A combination therapy with PEG-IFN and RBV was subsequently applied to patients with genotype 1 chronic hepatitis $\mathrm{C}$ with a high viral load.

Novel drug classes, including inhibitors of the NS3/S4 protease of $\mathrm{HCV}$ polyprotein (protease inhibitors), have recently become available (9-11).

Of these, telaprevir (TVR) was the first to be approved in Japan for the treatment of chronic hepatitis C. In a clinical
Table I. Clinical characteristics.

\begin{tabular}{lclll}
\hline $\begin{array}{l}\text { Case } \\
\text { no. }\end{array}$ & $\begin{array}{c}\text { Age, } \\
\text { years }\end{array}$ & Gender & $\begin{array}{c}\text { IL-28B } \\
\text { allele }\end{array}$ & $\begin{array}{c}\text { Previous type } \\
\text { of response }\end{array}$ \\
\hline 1 & 72 & Male & Major & SOC relapse \\
2 & 66 & Male & Minor & SOC null response \\
3 & 77 & Female & Minor & SOC relapse \\
4 & 85 & Female & Minor & SOC relapse \\
5 & 71 & Female & Minor & Naïve \\
6 & 72 & Male & Minor & SOC relapse \\
\hline
\end{tabular}

IL-28B, interleukin-28B; SOC, standard of care (peginterferon/rivabirin).

Table II. Comparison of the viral kinetics between the ART and CAP/CTM assays.

\begin{tabular}{lllcc}
\hline & & \multicolumn{2}{c}{ Viral kinetics value, Log IU/ml } \\
\cline { 3 - 5 } Case no. & Assay & Pre-treatment & 4 weeks & 8 weeks \\
\hline \multirow{2}{*}{1} & ART & 6.3 & ND & ND \\
& CAP/CTM & 6.2 & ND & ND \\
2 & ART & 6.2 & $<1.08$ & ND \\
& CAP/CTM & 6.2 & $<1.2$ & ND \\
3 & ART & 5.9 & 1.37 & $<1.08$ \\
& CAP/CTM & 6.1 & $<1.2$ & ND \\
4 & ART & 6.1 & 1.12 & ND \\
& CAP/CTM & 6.1 & ND & ND \\
5 & ART & 6.3 & $<1.08$ & ND \\
& CAP/CTM & 6.2 & ND & ND \\
6 & ART & 7.1 & ND & ND \\
& CAP/CTM & 7.2 & ND & ND \\
\hline
\end{tabular}

ART, Abbott RealTime hepatitis C virus (HCV) assay (AccuGENE m-HCV RNA quantitative assay assay); CAP/CTM, Cobas AmpliPrep/Cobas TaqMan assay (Cobas TaqMan HCV quantitative assay); ND, not detected.

trial of TVR triple combination therapy (TVR, PEG-IFN and RBV) for 24 weeks in Japan, rapid reductions in the serum HCV RNA levels were observed with an SVR rate of $\sim 70 \%(12,13)$.

Subsequently, SMV, a second-generation protease inhibitor, was included in the standard treatment regimen.

SMV is a second-generation NS3/NS4 protease inhibitor (14). The QUEST 1 and QUEST 2 phase 3 clinical trials demonstrated SVRs of 80 and $81 \%$, respectively, in patients treated with SMV triple combination therapy (SMV, PEG-IFN, and RBV). Similar results have been reported in phase 3 clinical trials conducted in Japan (15-17).

As the factors determining the effects of PEG-IFN/RBV combination therapy, which is the standard treatment strategy for refractory chronic hepatitis $\mathrm{C}$, the time required for the negative conversion of HCV RNA has attracted attention. 
Serial measurement of HCV-RNA loads and assessment of the rates of decrease in viral loads enable clinicians to make decisions regarding changes in treatment duration or to predict therapeutic outcomes.

It is essential to predict therapeutic outcomes in order to more accurately determine the time required for viral clearance or to more precisely understand viral kinetics in the treatment of chronic hepatitis $\mathrm{C}$.

In the present study, HCV-RNA loads were serially measured following treatment initiation by 2 types of quantitative polymerase chain reaction assays in patients with chronic hepatitis $\mathrm{C}$ who received $\mathrm{PEG}-\mathrm{IFN} / \mathrm{RBV} / \mathrm{SMV}$ triple-agent combination therapy, and the results of the two assays were compared and analyzed.

At 4 weeks after treatment initiation, 4 of the 6 patients were diagnosed as negative by the CAP/CTM assay, whereas 2 of these 4 patients were not found to be negative by the ART assay; 1 was signal-positive with an HCV-RNA load $<1.08 \mathrm{Log} \mathrm{IU} / \mathrm{ml}$ and the second had a viral load of $1.12 \mathrm{Log} \mathrm{IU} / \mathrm{ml}$. At 8 weeks after treatment initiation, one patient was found to be negative by the CAP/CTM assay, but signal-positive with a viral load $<1.08 \mathrm{Log}$ IU/ml by the ART assay. From 4 to 8 weeks after treatment initiation, 3 of the 6 patients appeared to be discrepant cases. Of the 6 patients who achieved an ETR, 4 were determined to have achieved a rapid virological response (RVR) by the CAP/CTM assay but may not have actually become negative.

As aforementioned, in patients who achieved an RVR but were found to have an extremely low HCV-RNA load during subsequent treatment, it is assumed that the HCV-RNA loads may serve as a predictive factor for relapse.

A recent study showed that in patients who become negative for HCV RNA at or after 12 weeks of treatment, the rate of complete response can be improved by the use of PEG-IFN/RBV combination therapy for 72 weeks (18). Although further studies with a larger sample size are required, the use of the highly sensitive HCV-RNA quantitative assay may improve the prediction of therapeutic outcomes. In discrepant cases showing slightly delayed negative conversion as determined by this assay, the patients should be regarded as late responders; the continuation of the PEG-IFN/RBV combination therapy may lead to further improvement of the therapeutic effects in such cases.

Although therapeutic outcomes have recently been improved, more accurate test methods are required to predict these therapeutic outcomes.

\section{References}

1. Davis GL: Monitoring of viral levels during therapy of hepatitis C. Hepatology 36 (Suppl 1): S145-S151, 2002.

2. Herrmann E, Lee JH, Marinos G, Modi M and Zeuzem S: Effect of ribavirin on hepatitis $\mathrm{C}$ viral kinetics in patients treated with pegylated interferon. Hepatology 37: 1351-1358, 2003.

3. Ferenci P, Fried MW, Shiffman ML, Smith CI, Marinos G, Gonçales FL Jr, Häussinger D, Diago M, Carosi G, Dhumeaux D, et al: Predicting sustained virological responses in chronic hepatitis $\mathrm{C}$ patients treated with peginterferon alfa-2a (40 KD)/ribavirin. J Hepatol 43: 425-433, 2005.

4. Jensen DM, Morgan TR, Marcellin P, Pockros PJ, Reddy KR, Hadziyannis SJ, Ferenci P, Ackrill AM and Willems B: Early identification of $\mathrm{HCV}$ genotype 1 patients responding to 24 weeks peginterferon alpha-2a (40 kd)/ribavirin therapy. Hepatology 43: 954-960, 2006
5. Morishima C, Morgan TR, Everhart JE, Wright EC, Shiffman ML, Everson GT, Lindsay KL, Lok AS, Bonkovsky HL, Di Bisceglie AM, et al; HALT-C Trial Group: HCV RNA detection by TMA during the hepatitis $\mathrm{C}$ antiviral long-term treatment against cirrhosis (Halt-C) trial. Hepatology 44: 360-367, 2006.

6. Gerotto M, Dal Pero F, Bortoletto G, Ferrari A, Pistis R, Sebastiani G, Fagiuoli S, Realdon S and Alberti A: Hepatitis C minimal residual viremia (MRV) detected by TMA at the end of Peg-IFN plus ribavirin therapy predicts post-treatment relapse. J Hepatol 44: 83-87, 2006.

7. Ghany MG, Strader DB, Thomas DL and Seeff LB; American Association for the Study of Liver Diseases: Diagnosis, management, and treatment of hepatitis C: An update. Hepatology 49: 1335-1374, 2009.

8. Izumi N: Diagnostic and treatment algorithm of the Japanese society of hepatology: A consensus-based practice guideline. Oncology 78 (Suppl 1): 78-86, 2010.

9. Jacobson IM, McHutchison JG, Dusheiko G, Di Bisceglie AM, Reddy KR, Bzowej NH, Marcellin P, Muir AJ, Ferenci P, Flisiak R, et al; ADVANCE Study Team: Telaprevir for previously untreated chronic hepatitis $\mathrm{C}$ virus infection. $\mathrm{N}$ Engl $\mathrm{J}$ Med 364: 2405-2416, 2011.

10. Poordad F, McCone J Jr, Bacon BR, Bruno S, Manns MP, Sulkowski MS, Jacobson IM, Reddy KR, Goodman ZD, Boparai N, et al; SPRINT-2 Investigators: Boceprevir for untreated chronic HCV genotype 1 infection. N Engl J Med 364: 1195-1206, 2011.

11. Zeuzem S, Andreone P, Pol S, Lawitz E, Diago M, Roberts S, Focaccia R, Younossi Z, Foster GR, Horban A, et al; REALIZE Study Team: Telaprevir for retreatment of HCV infection. N Engl J Med 364: 2417-2428, 2011.

12. Akuta N, Suzuki F, Hirakawa M, Kawamura Y, Yatsuji H, Sezaki H, Suzuki Y, Hosaka T, Kobayashi M, Kobayashi M, et al: Amino acid substitution in hepatitis $\mathrm{C}$ virus core region and genetic variation near the interleukin 28B gene predict viral response to telaprevir with peginterferon and ribavirin. Hepatology 52: 421-429, 2010.

13. Kumada H, Toyota J, Okanoue T, Chayama K, Tsubouchi H and Hayashi N: Telaprevir with peginterferon and ribavirin for treatment-naive patients chronically infected with $\mathrm{HCV}$ of genotype 1 in Japan. J Hepatol 56: 78-84, 2012.

14. Welch NM and Jensen DM: Pegylated interferon based therapy with second-wave direct-acting antivirals in genotype 1 chronic hepatitis C. Liver Int 35 (Suppl 1): 11-17, 2015.

15. Hayashi N, Izumi N, Kumada H, Okanoue T, Tsubouchi $H$, Yatsuhashi H, Kato M, Ki R, Komada Y, Seto C, et al: Simeprevir with peginterferon/ribavirin for treatment-naïve hepatitis $\mathrm{C}$ genotype 1 patients in Japan: CONCERTO-1, a phase III trial. J Hepatol 61: 219-227, 2014.

16. Izumi N, Hayashi N, Kumada H, Okanoue T, Tsubouchi H, Yatsuhashi H, Kato M, Ki R, Komada Y, Seto C, et al: Once-daily simeprevir with peginterferon and ribavirin for treatment-experienced HCV genotype 1-infected patients in Japan: The CONCERTO-2 and CONCERTO-3 studies. J Gastroenterol 49: 941-953, 2014.

17. Kumada H, Hayashi N, Izumi N, Okanoue T, Tsubouchi H, Yatsuhashi H, Kato M, Rito K, Komada Y, Seto C, et al: Simeprevir (TMC435) once daily with peginterferon- $\alpha-2 b$ and ribavirin in patients with genotype 1 hepatitis $\mathrm{C}$ virus infection: The CONCERTO-4 study. Hepatol Res 45: 501-513, 2015.

18. Sugawara K, Koushima Y, Inao M, Nakayama N, Nagoshi S, Yakabi K, Tamano M, Asabe S, Nishikawa K, Harada Y, Sekine C, Fukuya Y, Funyu J, Hashimoto Y and Mochida S: Multicenter prospective study to optimize the efficacy of triple therapy with telaprevir in patients with genotype $1 \mathrm{~b}$ hepatitis $\mathrm{C}$ virus infection according to an algorithm based on the drug Adherence, IL-28B Gene Allele and Viral Response Trial (AG \& RGT). Hepatol Res 45: 1091-1099, 2015. 